\section{Dimension of Rural Development in Nepal}

\section{Bala Ram Acharya ${ }^{1}$}

\section{Abstract}

Rural development in Nepal is a complex phenomenon involving an interaction of economic, social, political and cultural factors. The concept of rural development is a process of development and change to improve rural social life entirely. It is linked to infrastructural development, commercialization of agriculture, proper utilization and mobilization of resources, food security, creating opportunities, inclusive social development in the rural community and modernization of overall society. However, achievements of rural development efforts in Nepal are not satisfactory because of imposed development, unstable political situation, absence of people's participation, lack of research and political commitment.

Key Words: Rural development, rural poverty, human development in Nepal

\section{Background}

Nepal is a developing land-locked country with diverse cultural and ethnic identity. It covers an area of $147181 \mathrm{Sq}$. $\mathrm{Km}$. with an average width and length of $193 \mathrm{Km}$. and 885 $\mathrm{Km}$ respectively. It lies between two giant nations China and India. Nepal is divided into three diverse ecological zones; the Tarai (the plain), the Hills and the Mountain with distinct resources, opportunities and problems. Administratively, the country divided into 5 development region, 14 zones, 75

Mr. Bala Ram Acharya is a Lecturer in Sociology at Ratna Rajya Campus, Kathmandu. districts, 3915 village development committees and 58 municipalities. It is a multi caste, multi-religious and multi ethnic country. Broadly, Nepalese society is the composite form of Aryan and Mongolian people from its beginning. Economically, it has low human development. Unfortunately, latest development indicators are not satisfactory in comparison to other South Asian Countries. However, efforts of modern development have been continuing since 1956 through national planning. Politically, it is on the restructuring process of the state in the nature of republic federation after new constitution which will be prepared by constituent assembly. The population increased by nearly 18.5 million in 1991 to 23.1 million in 2001 with annual growth rate of 2.25 percent (CBS, 2002). Out of total land of Nepal about 77 percent is covered by mountains and hills. Topography of nation is one of important factors when considering overall development efforts. Development of Nepal has been affecting due to the unfavorable geographical setting. However, we are unable to identify the great potentialities of development on the basis of its resources in different geological variations. The population in urban areas is 14.2 percent of the total population in 2001. Majority of population is still live in rural areas with economically vulnerable life. Data shows that concentration of mass poverty is in the rural areas. Most village homes are empty of youth people. Old and sick parents and dependent children with women are facing social and economic problem due to the absence of their youth in the community. Most of the rural youth have been migrated to the mainly Arab countries and Malaysia increasingly for livelihood with very low salary due to the low level of skill and weak diplomatic relations between the countries. The total number permitted to go foreign employment by the government of Nepal till the April 
2007 is 9, 70,824 (Economic Survey, 2007). I think this is not good message for us those who want sustainable, prosperous and independent Nepal. Country's 80 percent people are into agriculture. But they have no minimum access on irrigation, often they are depend upon rain, locally called blessing of Lord Indra for water. Nepalese rural people are poor due to the lack of access to resources, low productivity, and land roads to obtain agricultural inputs and to sell agricultural produce.

\section{Conceptual Definition of Rural Development}

Human beings are born with certain potential capabilities. Therefore human society has been changing continuously from the very beginning of human history. I think development is the process of change. Definition and understanding of development depends on perception of people which is related to particular philosophical orientation and individual experiences and expectations. We shouldn't forget development must be related to quality of life with independent achievement. Every people of every one want to be free him/her from servitude. They want to live with selfrespect, self-identity and self-dignity. Therefore, development is not only an economic issue but also social, cultural and political realization.

Rural development is a strategy to enable a specific group of people. It involves helping the poorest among those who seek a livelihood in the rural area to demand and control more of the benefits of rural development. The group includes small scale farmers, tenants, and the landless (Chamber1983:147). Rural development is a complex phenomenon involving an interaction of economic, social, political and cultural factors. It is a multidisciplinary process of development which seeks transformation of the society from traditional to modern nature. The concept of rural development is a process of development and change to improve rural social life. The goal of rural development can not be achieved without available infrastructural development, commercialization of agriculture, proper utilization and mobilization of resources and inclusive social development. The term rural development connotes over all development of rural areas with a view to improve the quality of life of rural people (Singh, 1999:20). Theoretically, rural development seeks to alleviate poverty, mass utilization of resources, commercialization of agriculture, food security, creating opportunities, infrastructural development of rural community and modernization of overall society. However there are bias in the process of rural development as identified by Robert Chamber (1983:13-26); those are spatial biases, project biases, person biases, dry season biases, diplomatic biases, and professional biases. Similarly, World Bank (1975) has defined of rural development as strategy designed to improve the socio-economic life of rural poor; as such it involves extending the benefits of development to poorest in rural areas e.g. small farmers, tenants, landless and other disadvantage group. In my opinion process of rural development at least should be concerned on physical and social infrastructure, livelihood opportunities, economic activities related to rural community, environmental vulnerability, demographic change, food security, house and land, social adjustment, empowerment and development of social capabilities and inclusion.

\section{Process of Rural Development in Nepal}

Process of modern development in Nepal has been started after 1950 when family based political system called 'Rana 


\section{Dhaulagiri Journal of Sociology and Anthropology Vol.2 | 185}

Rule' ended and country has entered into the democratic system by the influence of people's movement and political influence of outer world. Development planning was started in the country in 1955-56 to bring about systematic change in the underdeveloped socio-economic condition. Tenth Plans have already been completed and interim three years plan is running at present. We could not get satisfactory output in the history of overall process of planning and development in Nepal due to the unstable political economy and center oriented development mechanisms.

Government of Nepal has tried to adopt rural development approach for the development of rural areas after 1950s by the integrated rural development program. Obviously, effort of rural development in Nepal has a few achievements as compared to its inputs. Most of the integrated rural development program in Nepal has faced problems because of irrelevant program to the target groups and lack of proper evaluation and monitoring system.

Different rural development programs have been conducted after 1951. The first rural development program in Nepal was Tribhuvan Village Development Program which was mainly focused on the development of agriculture, road, drinking water, education and health. Development programs in rural community by the initiation of Block Development Officer (Adhikari, 1982). Panchayet Development Program was established in the decade of 1960s which has three main objectives for development and change. They were institutional development, social mobilization and attitudinal change.

Similarly, different integrated rural development programs have been conducted since the decade of 1970s and continued later giving priority on saving, road, training, health, agriculture, rural industry, nutrition etc. Experiments on the

\section{6 | Bala Ram Acharya}

rural development in Nepal started since 1956 but its impacts are debatable. It is difficult to isolate benefits achieved through rural development program only, the role of local institutions have not been able to take initiative and generates resources (Pyakural, 1980:27). Different rural development programs like Rural Infrastructure Work, Rural Infrastructure Development Program, Agricultural Road Program, Rural access Program, District Road Support Program, Poverty Alleviation Project, Remote and Specific Area Development Program, Periodic District Development Plan have been implemented in the Ninth five year plan for the development of rural sector specifically. Output of rural development or local development does not seem satisfactory due to the inability to prioritize project to rural development, lack of political consensus to the local development, no feasibility study on the rural development program and absence of local bodies. However, Rural Community Infrastructure Work implemented in additional 15 districts, 47 District Development Committees have prepared District Transport Master Plan, different suspension bridges have been constructed in the rural sector, different poverty alleviation project implemented in eight Tarai districts of Western Nepal in the Ninth Plan.

The objective of Tenth Plan for local development was to minimize poverty by making available local people, particularly the people of socially and economically backward areas, caste, nationalities groups an access to services and benefits made locally available. During the Tenth Plan, local development programs like local body strengthen program, policy and institutional reform programs, financial resource management program, human resource development program, local infrastructure development program, economically backward areas and people's upliftment and development program, social mobilization and self-employment program, integrated reproductive health and 


\section{8 | Bala Ram Acharya}

population education program have been implemented (Tenth Plan, 2002-2007).

The goal of rural development is to eradicate poverty. However, only a few targets of the Tenth Plan have been achieved during the period of 2003-2007. Currently, interim plan has been implementing at the end of 2007. Major objectives of this plan are to reduce poverty, unemployment and inequality for social and economic transformation. It focuses on target program to the marginalized people, social mobilization, infrastructure development, strengthening to local bodies, regional development, reconstructing local infrastructure, and reformation of local governance for rural development and change.

\section{Indicators of Rural Development in Nepal}

Level of rural development in Nepal is low in comparison to urban indicators. People of rural areas have low access on education, health, communication, electricity, road etc. Similarly, Dalit, women, marginal ethnic groups, Madhesi people of remote area and disable people have very low access on basic human requirements. Unequal poverty index between the rural and urban areas is exemplified in table no 1.

Table No. 1: Poverty measurement (1996 and 2005)
\begin{tabular}{|c|c|c|c|c|c|c|}
\hline Area & \multicolumn{2}{|c|}{$\begin{array}{c}\text { Population below of } \\
\text { the poverty line }\end{array}$} & \multicolumn{2}{|c|}{ Poverty gap } & \multicolumn{2}{|c|}{$\begin{array}{c}\text { Severity of } \\
\text { Poverty }\end{array}$} \\
\cline { 2 - 7 } & 1996 & 2003 & 1996 & 2003 & 1996 & 2003 \\
\hline Urban & 21.55 & 9.55 & 6.54 & 2.18 & 2.65 \\
& & 34.62 & 12.14 & 8.50 & 4.83 \\
\hline Rural & 43.27 & & & & 3.05 \\
\hline Nepal & 41.76 & 30.84 & 11.75 & 7.55 & 4.67 \\
& & & & & 2.60 \\
\hline
\end{tabular}

Source: Economic Survey 2007
Facts in table 1 show the decreasing trend of poverty in Nepal. However, decreasing trend seems unequal in rural and urban areas during ten years time period. Does it mean irrelevance development programs were conducted particularly in rural areas? Or was it the result of unstable, irresponsible and dominated political economy in the process of development history of Nepal? It should be evaluated by the independent agencies. I think cause of underdevelopment of the rural areas is not only the result of present phenomena but also the nature of political economy of Nepal.

As pointed out in the Tenth five year plan (2002-2007), the progress in Human Development Indicators (HDI) is rapid as compared that of per capita of Nepal. The achievements made in extension and development of education, health and drinking water have clearly surpassed the economic growth rate. There are noticeable differences among the urban and rural areas which are given in table no 2 .

Table No. 2: HDI of rural and urban region 1990 and 2000

\begin{tabular}{|l|l|l|l|l|l|l|l|l|}
\hline Region & \multicolumn{2}{|c|}{$\begin{array}{c}\text { Adult literacy } \\
\text { rate (above 15 } \\
\text { years }\end{array}$} & $\begin{array}{c}\text { Life } \\
\text { expectancy } \\
\text { (years) at } \\
\text { birth }\end{array}$ & $\begin{array}{c}\text { Population } \\
\text { having safe } \\
\text { drinking } \\
\text { water }\end{array}$ & \multicolumn{2}{|c|}{ HDI } \\
\cline { 2 - 10 } & 1996 & 2000 & 1996 & 2000 & 1996 & 2000 & 1996 & 2000 \\
\hline Urban & 63.5 & 69 & 55 & 71.1 & 62 & 93.3 & 0.518 & 0.616 \\
\hline Rural & 34.5 & 48 & 53.7 & 58.7 & 61 & 78.1 & 0.306 & 0.466 \\
\hline Nepal & 36.7 & 50.7 & 55 & 59.5 & 61 & 79.9 & 0.325 & 0.466 \\
\hline
\end{tabular}

Source: Nepal Human Development Report 1998 and 2000

The indicators in table 2 prove that level of human development in urban areas is higher. Similarly, major indicators of human development are not concentrated equally between caste and ethnic groups or male and female 


\section{Dhaulagiri Journal of Sociology and Anthropology Vol.2 | 189}

or deprived groups like Dalits, Madhesi and other marginal section of community.

Most recent major indicators of development are given in table no 3 which are helpful to understand.

Table No. 3: Major Indicators of Development in Nepal

\begin{tabular}{|c|c|c|c|}
\hline S.N. & Major Indicators of Development & $\begin{array}{l}\text { Status of } \\
2007\end{array}$ & $\begin{array}{l}\text { Target up to } \\
\text { Interim Plan }\end{array}$ \\
\hline $\begin{array}{l}1 . \\
2 . \\
3 . \\
4 . \\
5 . \\
6 . \\
7 . \\
8 . \\
9 . \\
10 . \\
11 . \\
12 . \\
13 . \\
14 . \\
15 . \\
16 .\end{array}$ & $\begin{array}{l}\text { Annual Economic growth rate (\%) } \\
\text { Agriculture (\%) } \\
\text { Non-agriculture (\%) } \\
\text { Population below poverty line (\%) } \\
\text { Employment growth rate } \\
\text { Human Development Index (HDI) } \\
\text { Gender Development Index (GDI) } \\
\text { Literacy above (6) years (\%) } \\
\text { Population with electricity (\%) } \\
\text { Population with basic drinking } \\
\text { water (\%) } \\
\text { District connected with road } \\
\text { network } \\
\text { Population with NTV (\%) } \\
\text { Population with internet services } \\
\text { in district } \\
\text { Population with sanitation (\%) } \\
\text { Irrigation (hectors) } \\
\text { Population with electricity } \\
\text { services }\end{array}$ & $\begin{array}{l}2.5 \\
0.7 \\
3.6 \\
31 \\
3.0 \\
0.534 \\
0.520 \\
63 \\
48.5 \\
77 \\
\\
63 \\
80 \\
\\
59 \\
46 \\
11,68,144 \\
48.5\end{array}$ & $\begin{array}{l}5.5 \\
3.6 \\
6.5 \\
24 \\
3.5 \\
0.570 \\
0.556 \\
76 \\
58.5 \\
85 \\
75 \\
100 \\
- \\
60 \\
12,63,824 \\
58.5\end{array}$ \\
\hline
\end{tabular}

National indicators of development are unable to represent the distribution pattern of development of different social groups and regions. For example, population below the poverty line of Dalits, hill ethnic groups and Muslims are $46 \%, 44 \%$ and $41 \%$ respectively. At the same time, facts in table no 3 show that $45.2 \%$ of people from Himali region, $41.8 \%$ of people from Hill region and $37.4 \%$ of people from Tarai region are out of access on consumption of minimum

\section{0 | Bala Ram Acharya}

level of calories. Similarly, marginal section and disadvantage group have very low access on social and development.

Without committed development efforts through high level political consensus on the basis of concentration of poverty with diverse nature in the different communities, it will be very difficult to escape people from vicious circle of poverty. Development and underdevelopment of Nepal is still being national issues and discourse due to the low access on education, opportunities, social security, health, infrastructural development and productivity of the different communities with momentous disparities. The gap between rural and urban areas should be controlled to attain national goal of development. We always want socially justiceable, equitable, prosperous, self-respected, independent Nepali citizen. Government should provide high priority on rural development legally and morally in the process of planning and development in Nepal where huge volume of population is concentrated. Political commitment with consensus between the parties is essential to build prosperous and independent Nepal. It is only the way of sustainable rural development which will be fruitful to reduce poverty. Participatory model of development is fruitful to maintain sustainable development in the country.

\section{Conclusion}

Indeed, Nepal is an underdeveloped country in South Asian region. The rate of population below the poverty line is in decreasing trend. Unfortunately, equal distribution of development is difficult in terms of its social, regional and cultural diversity. To improve entire socio-economic condition of rural people, we have to change trickle down model of development which in practice since1956. We have to try development honestly through decentralization and multidisciplinary approaches in which every section of 
Dhaulagiri Journal of Sociology and Anthropology Vol.2 | 191

population or community can be involved in their own development process. Without commercialization of agriculture no one can hope rural development properly. Eighty percent of Nepalese people depend on subsistence agriculture. I think enabling local community to identify their resources and let them to mobilize for local development can best support to infrastructural development concerning to the rural areas. It is essential to identify patterns of poverty, inequality, exclusion and vulnerability of the rural sector or rural community to prepare proper development plan for rural development and change in Nepal.

\section{Reference}

Adhikari Shyam Prasad (1982). IntegratedRural Development in Nepal. Kathmandu: Sahayogi Press, Nepal

Amarty Sen (2003). Poverty and Famines: An Essay on Entitlement and Deprivation. Oxford University Press, Seventh Impression.

CBS (2003). Population Monograph, Vol I. Kathmandu: CBS

Katar Singh (1999). Rural Development, Principle, Policies and Management( $2^{\text {nd }}$ edition). New Delhi: Sage Publication.

Korten, David C (1990). Getting to 21st Century, Voluntary Action and Global Agenda, Oxford and IBH Publishing Company Pvt. Ltd.

Nepal Government (2007). Economic Survey, 2007, Nepal Government, Ministry of Finance.

NPC (2007) Interim Plan, (2007-2010). Kathmandu: Nepal Government Singha Darbar.

NPC (1997). Ninth Plan, (1997-2002), HMG/Nepal Singha Darbar, Kathmandu, Nepal.

\section{2 | Bala Ram Acharya}

NPC (2002). Tenth Plan, 2002-2007. Kathmandu: HMG/Nepal Singha Darbar, Nepal.

Panday, Devendra Raj (1999). Nepal's Failed Development, Reflection on the Modern Mission and the Maladies. Nepal South Asia Centre.

Pieterse Jan Nedervee (2001). Development Theory, Constructions and Reconstructions. Delhi: Vistaar Publication.

Pyakuryal, Kiran N. (1980). The Concept and Operation of Rural Development. Kathmandu: CEDA Publication Strategic Elements of Rural Development.

Robert Chambers (1983).Rural Development: Putting the Last First. Pearson Education Limited.

Santosh Kumar Bista (2000) Rural Development In Nepal: An Alternative Strategy. Kathmandu :Udaya Books.

UNDP (2001). Nepal Human Development Report. UNDP Wolfgang Sachs (Ed) (1992). Development Dictionary: A Guide to Knowledge of Power. Orient Longman. 